\title{
GDF-15 gene expression alterations in human lymphoblastoid cells and peripheral blood lymphocytes following exposure to ionizing radiation
}

\author{
SHUANG LI $^{1 *}$, QING-ZHAO ZHANG ${ }^{1 *}$, DE-QIN ZHANG ${ }^{2 *}$, JIANG-BIN FENG $^{1}$, QUN LUO ${ }^{3}$, XUE LU $^{1}$, \\ XIN-RU WANG ${ }^{4}, \mathrm{KUN}$-PENG LI ${ }^{5}$, DE-QING CHEN ${ }^{1}, \mathrm{XIAO}$-FENG MU ${ }^{5}$, LING GAO $^{1}$ and QING-JIE LIU ${ }^{1}$ \\ ${ }^{1}$ China CDC Key Laboratory of Radiological Protection and Nuclear Emergency, National Institute for Radiological \\ Protection, Chinese Center for Disease Control and Prevention, Beijing 100088; ${ }^{2}$ Beijing Shijingshan Center for \\ Disease Control and Prevention, Beijing 100043; ${ }^{3}$ Department of Transfusion, Chinese PLA General Hospital, \\ Beijing 100853; ${ }^{4}$ Department of Clinical Laboratory, Second Artillery General Hospital PLA, Beijing 100088; \\ ${ }^{5}$ Department of Radiotherapy, General Hospital of Armed Police Forces, Beijing 100039, P.R. China
}

Received March 4, 2016; Accepted February 20, 2017

DOI: $10.3892 / \mathrm{mmr} .2017 .6476$

\begin{abstract}
The identification of rapid, sensitive and highthroughput biomarkers is imperative in order to identify individuals harmed by radiation accidents, and accurately evaluate the absorbed doses of radiation. DNA microarrays have previously been used to evaluate the alterations in growth/differentiation factor 15 (GDF15) gene expression in AHH-1 human lymphoblastoid cells, following exposure to $\gamma$-rays. The present study aimed to characterize the relationship between the dose of ionizing radiation and the produced effects in GDF-15 gene expression in AHH-1 cells and human peripheral blood lymphocytes (HPBLs). GDF-15 mRNA and protein expression levels following exposure to $\gamma$-rays and neutron radiation were assessed by reverse transcription-quantitative polymerase chain reaction and western blot analysis in AHH-1 cells. In addition, alterations in GDF-15 gene expression in HPBLs following ex vivo irradiation were evaluated. The present results demonstrated that GDF-15 mRNA and protein expression levels in AHH-1 cells were significantly upregulated following exposure to $\gamma$-ray doses ranging between 1 and $10 \mathrm{~Gy}$, regardless of the dose rate. A total of $48 \mathrm{~h}$ following exposure to neutron radiation, a
\end{abstract}

Correspondence to: Dr Qing-Jie Liu or Dr Ling Gao, China CDC Key Laboratory of Radiological Protection and Nuclear Emergency, National Institute for Radiological Protection, Chinese Center for Disease Control and Prevention, 2 Xinkang Street, Beijing 100088, P.R. China

E-mail: qjliu@nirp.cn

E-mail: gaolingxinxin@126.com

*Contributed equally

Key words: ionizing radiation, growth differentiation factor 15 , gene expression, dose-effect, neutron, $\gamma$-rays dose-response relationship was identified in AHH-1 cells at $\gamma$-ray doses between 0.4 and $1.6 \mathrm{~Gy}$. GDF-15 mRNA levels in HPBLs were significantly upregulated following exposure to $\gamma$-ray doses between 1 and $8 \mathrm{~Gy}$, within $4-48 \mathrm{~h}$ following irradiation. These results suggested that significant time- and dose-dependent alterations in $G D F-15$ mRNA and protein expression occur in AHH-1 cells and HPBLs in the early phases following exposure to ionizing radiation. In conclusion, alterations in $G D F-15$ gene expression may have potential as a biomarker to evaluate radiation exposure.

\section{Introduction}

Gene expression is sensitive to environmental factors such as ionizing radiation. Radiation-induced alterations in gene expression profiles in humans and animal models have been analyzed in an effort to identify biomarkers suitable for the accurate estimation of the radiation dose in exposed individuals (1-10). DNA microarrays for gene expression profile analysis have been used as a novel screening method for the identification of novel biomarkers, as they are able to simultaneously assess alterations in the expression of thousands of genes (3,11-17). Quantitative polymerase chain reaction (qPCR) is often performed to validate microarray results. Alterations in the expression of numerous genes have been identified in irradiated cell lines and human peripheral blood lymphocytes (HPBLs) (18-23). Previous studies in mouse and human models have reported that the patterns of alteration in gene expression induced by radiation are specific, durable and can accurately reflect radiation exposure $(24,25)$.

Previous studies have reported that alterations in the expression of certain genes following exposure to radiation are dose- or time-dependent within a specific dose range or duration of treatment $(2,4,26-28)$. Various radiation-responsive genes, including growth arrest and DNA damage-inducible 45 (GADD45), cyclin-dependent kinase inhibitor 1A (CDKN1A), mouse double minute 2 homolog and proliferating cell nuclear antigen (PCNA), have been identified as downstream targets 
of tumor protein $53(6,18,29)$. A previous study demonstrated that the $\gamma$-ray-induced GADD45 upregulation in HPBLs is a linear dose-response relationship after 24 and $48 \mathrm{~h}$ of 0-3 Gy irradiation (6). In addition, in human blood samples exposed to various $\gamma$-ray doses $(0.5,2,5$ and $8 \mathrm{~Gy})$, alterations in the expression of five genes, including $C D K N 1 A$, were detected at $24 \mathrm{~h}$ post-irradiation (29). However, a specific pattern of radiation-induced alterations in gene expression, that is consistent across cell types, doses and duration of exposure, has yet to be characterized. The analysis of the alterations in the expression of radiation-responsive genes has potential as a strategy to detect radiation exposure; however, its limitations need to be addressed prior to its establishment as a method for the assessment of radiation exposure in clinical practice (30).

Identifying genes and dose-response models with the highest reproducibility is necessary to establish a gene expression signature database for rapid, reliable and high-throughput biodosimetry following radiation exposure (31-35). Gene expression studies in human primary fibroblasts, keratinocytes (36-38) and pulmonary epithelial cells (19) suggested that growth/differentiation factor $15(G D F-15)$, which is also a target gene of $\mathrm{p} 53$, is a radiation-responsive gene. Radiation-induced alterations in $G D F-15$ expression are correlated with the time and dose of radiation exposure $(19,34)$. Previous microarray analysis in our laboratory, demonstrated that $G D F-15$, among other genes, was consistently upregulated in AHH-1 human lymphoblastoid cells following exposure to $0.5,3$ and 8 Gy of ${ }^{60} \mathrm{Co} \gamma$-rays (39).

In the present study, the relationship between alterations in $G D F-15$ expression and the dose of ionizing radiation was investigated in AHH-1 cells and HPBLs. Alterations in $G D F-15$ expression in AHH-1 cells were examined at various time points following exposure to a wide range of ${ }^{60} \mathrm{Co} \gamma$-ray and neutron radiation doses. Since HPBLs are sensitive to radiation-induced damage and can be easily sampled, they were used to validate the results obtained in AHH-1 cells. Alterations in GDF-15 mRNA expression levels in HPBLs irradiated ex vivo with $\gamma$-rays were investigated at various time points following exposure, and using a wide range of radiation doses. In addition, baseline $G D F-15$ gene expression levels were quantified in HPBLs from healthy adult donors.

\section{Materials and methods}

Cell culture. The AHH-1 cell line, which is a human B lymphocyte cell line derived from a 33-year-old Caucasian male and immortalized by Epstein-Barr virus (40), was obtained from American Type Culture Collection (Manassas, VA, USA). AHH-1 cells were cultured in RPMI-1,640 medium (Thermo Fisher Scientific, Inc., Waltham, MA, USA), supplemented with $10 \%$ heat-inactivated fetal bovine serum (FBS; HyClone; GE Healthcare Life Sciences, Logan, UT, USA), 2 mM l-glutamine (Thermo Fisher Scientific, Inc.), $100 \mathrm{U} / \mathrm{ml}$ penicillin (Sigma-Aldrich; Merck KGaA, Darmstadt, Germany) and $100 \mathrm{mg} / \mathrm{ml}$ streptomycin (Sigma-Aldrich; Merck KGaA). The AHH-1 cell line is diploid and its population doubling time ranges between 16 and $19 \mathrm{~h}$. AHH-1 cells were incubated at $37^{\circ} \mathrm{C}$ in a humidified $5 \% \mathrm{CO}_{2}$ atmosphere. AHH-1 cells in the exponential phase of growth were seeded in flasks at a density of $1 \times 10^{7}$ cells $/ \mathrm{ml}$ and prepared for irradiation.
Human peripheral blood samples. Blood samples from 73 healthy adult donors (39 males and 34 females; age, 20-60 years) were obtained for the quantification of baseline GDF-15 mRNA expression levels. The eligibility of the donors was evaluated using questionnaires and regular medical examination. Peripheral blood samples $(4 \mathrm{ml})$ were collected from each subject. Radiation-induced alterations in $G D F-15$ gene expression were investigated in peripheral blood samples from 3 healthy adult male subjects (aged 26, 29 and 41 years). The subjects had no history of chronic disease, substance abuse, smoking, or toxic chemical exposure. In addition, they had not been exposed to radiation or had a history of viral infections during the months preceding the study.

The present study was approved by the Ethics Committee of the National Institute for Radiological Protection, Chinese Center for Disease Control and Prevention (Beijing, China). Written informed consent was obtained from all human subjects prior to enrollment in the present study. Experiments were conducted according to the principles outlined in the Declaration of Helsinki.

Sample irradiation. Irradiation with ${ }^{60} \mathrm{Co} \gamma$-rays was performed in the Beijing Radiation Center (Beijing, China). The source radioactivity was $130 \mathrm{TBq}$. The exposure setup was calibrated by physical measurement using a tissue-equivalent ionizing chamber. The radiation dose rate was calculated using the source radioactivity and the distance between the source and sample: A dose rate of $1 \mathrm{~Gy} / \mathrm{min}$ corresponded to a source-sample distance of $73.5 \mathrm{~cm}$. The homogeneous irradiation field was $30 \times 30 \mathrm{~cm}$; the samples were placed within a $5 \mathrm{~cm}$-radius circle and the uncertainty of the calibration was $1 \%$. AHH-1 cells were seeded in flasks $\left(1 \times 10^{7}\right.$ cells $\left./ \mathrm{ml}\right)$ and irradiated. Radiation doses of $0,1,3,5,8$ and $10 \mathrm{~Gy}$, at a dose rate of $1 \mathrm{~Gy} / \mathrm{min}$, were used in the dose-response experiment; doses of 3, 5 and $8 \mathrm{~Gy}$, at a dose rate of $0.5,1$ and $2 \mathrm{~Gy} / \mathrm{min}$ were used to investigate the effect of various dose rates. Irradiated AHH-1 cells were incubated at $37^{\circ} \mathrm{C}$ for $8-168 \mathrm{~h}$ prior to further analysis.

Peripheral blood samples $(20 \mathrm{ml})$ were collected from each subject via venipuncture into Vacutainers (BD Biosciences, Franklin Lakes, NJ, USA). A total of 5 different radiation doses were used $(0,1,3,5$ and $8 \mathrm{~Gy})$. Blood samples were divided into five plastic centrifuge tubes, one tube per dose group, and irradiated with a single dose of ${ }^{60} \mathrm{Co} \gamma$-rays at a dose rate of $1 \mathrm{~Gy} / \mathrm{min}$. Following irradiation, blood samples were incubated at $37^{\circ} \mathrm{C}$ for $4-72 \mathrm{~h}$ in RPMI-1640 medium of equal volume, supplemented with $10 \%$ FBS.

Neutron irradiation was performed at the General Hospital of Armed Police Forces (Beijing, China), using a ${ }^{252} \mathrm{Cf}$ neutron source. AHH-1 cells were irradiated with $0,0.4,0.8,1.2$ and $1.6 \mathrm{~Gy}$, at dose-rate of $0.073 \mathrm{~Gy} / \mathrm{min}$. The dose-rate was calibrated using a tissue-equivalent ionizing chamber prior to irradiation. The homogeneous irradiation field was 10x10 cm; the samples were placed within a $5 \mathrm{~cm}$-radius circle and the uncertainty of the calibration was $3 \%$. Irradiated AHH-1 cells were incubated at $37^{\circ} \mathrm{C}$ for $48 \mathrm{~h}$ prior to further analysis.

Reverse transcription-qPCR (RT-qPCR). Total RNA was extracted from AHH-1 cells using TRIzol ${ }^{\circledR}$ reagent (Invitrogen; Thermo Fisher Scientific, Inc.) and reverse 
transcribed into cDNA using a Reverse Transcription system kit (Promega Corporation, Madison, WI, USA), according to the manufacturer's protocol. Individual PCR reactions were carried out in $20 \mu \mathrm{l}$ samples in a 96-well plate (Applied Biosystems $^{\mathrm{TM}}$; Thermo Fisher Scientific, Inc.), containing $0.5 \mu \mathrm{l}$ of each forward and reverse primer (10 $\mu \mathrm{M}$ each), $2 \mu \mathrm{l}$ cDNA, $7 \mu \mathrm{l}$ distilled water and $10 \mu \mathrm{l}$ 2X SYBR-Green PCR Master Mix (Applied Biosystems ${ }^{\text {TM }}$; Thermo Fisher Scientific, Inc.). qPCR was performed using the 7500 Fast Real-Time PCR System (Applied Biosystems ${ }^{\mathrm{TM}}$; Thermo Fisher Scientific, Inc.). Amplification was performed under the following conditions: Initial cycle at $95^{\circ} \mathrm{C}$ for $10 \mathrm{~min}$, followed by 40 cycles at $95^{\circ} \mathrm{C}$ for $15 \mathrm{sec}$ and at $60^{\circ} \mathrm{C}$ for $1 \mathrm{~min}$. The following primers were used: $G D F-15$, forward 5'-GTT AGC CAA AGA CTG CCA CTG-3', reverse 5'-CCT TGA GCC CAT TCC ACA-3'; and $\beta$-actin, forward 5'-ACT TAG TTG CGT TAC ACC CTT TCT-3' and reverse 5'-GAC TGC TGT CAC CTT CAC CGT-3'. The relative expression levels for each gene were normalized to $\beta$-actin and analyzed using the $2^{-\Delta \Delta C q}$ method (41) with the 7500 Sequence Detection software. Each group, composed of three parallel samples, was analyzed after irradiation. All experiments were performed three times.

Lymphocytes were isolated from human blood samples using Ficoll-Paque PLUS (GE Healthcare Life Sciences, Chalfont, UK), according to the manufacturer's protocol. Total RNA was extracted from HPBLs using TRIzol ${ }^{\circledR}$ reagent (Invitrogen; Thermo Fisher Scientific, Inc.) and reverse transcribed into cDNA using a Reverse Transcription system kit (Promega Corporation), according to the manufacturer's protocol. qPCR was performed on cDNA using a TaqMan ${ }^{\circledR}$ MGB probe (Thermo Fisher Scientific, Inc.). PCR was performed using a standard curve established using 10-fold successively diluted known copy numbers of a GDF-15 standard. The standard was prepared from the pUC57 plasmid containing GDF-15 cDNA (Thermo Fisher Scientific, Inc.). The plasmid was quantified based on the cDNA concentration determined using UV spectroscopy; stock solutions were prepared in Tris-EDTA buffer that ranged in concentration between $10^{2}$ and $10^{8} \mathrm{cDNA}$ copies $/ \mu 1$. A standard cDNA curve for the range of $10^{2}-10^{8} \mathrm{cDNA}$ copies per reaction was generated by analyzing $2 \mu \mathrm{l}$ of each dilution in triplicate using a TaqMan ${ }^{\circledR}$ MGB probe. The oligonucleotide primers for $G D F-15$ and thermocycling conditions for qPCR were as aforementioned. Individual PCR reactions were carried out in $20 \mu \mathrm{l}$ samples in a 96-well plate containing $G D F-15$ primers, $2 \mu 1$ cDNA, $7 \mu$ ld distilled water and $1 \mu \mathrm{l}$ TaqMan ${ }^{\circledR}$ Gene Expression Master Mix (Applied Biosystems ${ }^{\mathrm{TM}}$; Thermo Fisher Scientific, Inc.). mRNA expression levels (mRNA copy numbers/ $\mu 1$ ) were calculated based on the standard curve. Each group, composed of three parallel samples, was analyzed after the irradiation. All experiments were performed three times.

Western blot analysis. AHH-1 cells were washed with PBS, lysed in lysis buffer containing $50 \mathrm{mM}$ Tris- $\mathrm{HCl}(\mathrm{pH} 7.4)$, $150 \mathrm{mM} \mathrm{NaCl}, 1 \mathrm{mM}$ EDTA, $1 \% \mathrm{NP}-40$ and $10 \mu \mathrm{g} / \mathrm{ml}$ protein inhibitor (Roche Diagnostics, Basel, Switzerland), and centrifuged for $20 \mathrm{~min}$ at $5,000 \mathrm{x} \mathrm{g}$ and $4^{\circ} \mathrm{C}$. Supernatants were collected and protein concentrations were determined using the bicinchoninic acid method. Equal amounts of extracted protein $(50 \mu \mathrm{g})$ were separated by $12 \%$ SDS-PAGE and transferred onto nitrocellulose membranes (GE Healthcare Life Sciences, Shanghai, China). Membranes were blocked for $1 \mathrm{~h}$ with TBS containing $0.05 \%$ Tween-20 (TBST) with 5\% non-fat dry milk at room temperature. Subsequently, membranes were incubated at $4^{\circ} \mathrm{C}$ overnight with rabbit polyclonal anti-GDF-15 (cat. no. BS3872; 1:500; Biogot Technology Co., Ltd., Nanjing, China) and mouse monoclonal anti- $\beta$-actin (cat. no. SC-47778; 1:1,000; Santa Cruz Biotechnology, Inc., Dallas, TX, USA) primary antibodies. Membranes were washed three times with TBST prior to incubation for $2 \mathrm{~h}$ with horseradish peroxidase-conjugated anti-rabbit IgG (cat. no. ZB-5301; 1:5,000; Beijing Zhongshan Golden Bridge Biotechnology Co., Ltd., Beijing, China) and horseradish peroxidase-conjugated anti-mouse IgG (cat. no. ZB-2305; 1:5,000; Beijing Zhongshan Golden Bridge Biotechnology Co., Ltd.) secondary antibodies at $37^{\circ} \mathrm{C}$. Protein bands were visualized using an Enhanced Chemiluminescence kit (GE Healthcare Life Sciences), according to the manufacturer's protocol, and analyzed using the ChemiDoc ${ }^{\mathrm{TM}}$ XRS+system (Bio-Rad Laboratories, Inc., Hercules, CA, USA). The scanned films were semi-quantified using the UVP EC3 Imaging system (UVP, Inc., Upland, CA, USA). GDF-15 protein levels were normalized to $\beta$-actin, which was used as the loading control.

Statistical analysis. Statistical analysis was performed using the SPSS software version 16.0 (SPSS Inc., Chicago, IL, USA). The statistical significance of the difference between groups was assessed by one-way analysis of variance (ANOVA). Least significant difference and Student-Newman-Keuls tests were used to compare individual groups following ANOVA. A $\chi^{2}$ test was used to compare differences in gene expression levels between sexes and among age groups of healthy adults. A linear regression method was used to establish the dose-response equation. ANOVA was used to analyze the significance of the equation of the dose-response regression curve. Results are presented as the mean+standard error of the mean. $\mathrm{P}<0.05$ was considered to indicate a statistically significant difference.

\section{Results}

Exposure to $\gamma$-rays alters GDF-15 mRNA expression levels in $A H H-1$ cells. Dose-dependent alterations in GDF-15 mRNA expression levels of irradiated AHH-1 cells were assessed using RT-qPCR at 8, 12, 24, 48, 72, 120 and $168 \mathrm{~h}$ after exposure to $0,1,3,5,8$ and 10 Gy of $\gamma$ radiation. The results demonstrated that $G D F-15$ mRNA expression levels were significantly upregulated in a dose-dependent manner at 8 -120 h following $\gamma$-ray exposure $(\mathrm{P}<0.05$; Fig. 1A). $\gamma$ irradiation appeared to reach its maximum effect ( 14-fold increase compared with the control group) at $10 \mathrm{~Gy}$ and $12 \mathrm{~h}$ post-irradiation. The dose-response curves describing the relationship between radiation dose and $G D F-15$ relative expression levels between 8 and 120 h post-exposure were fitted to a linear model $(\mathrm{P}<0.05$; Table I). No dose-response relationship was apparent at $168 \mathrm{~h}$ post-irradiation.

To investigate the association between the radiation dose rate and GDF-15 mRNA expression levels, AHH-1 cells were irradiated with 3,5 and 8 Gy of ${ }^{60} \mathrm{Co} \gamma$-rays at dose rates of $0.5,1$ and $2 \mathrm{~Gy} / \mathrm{min}$. GDF-15 mRNA expression levels were 


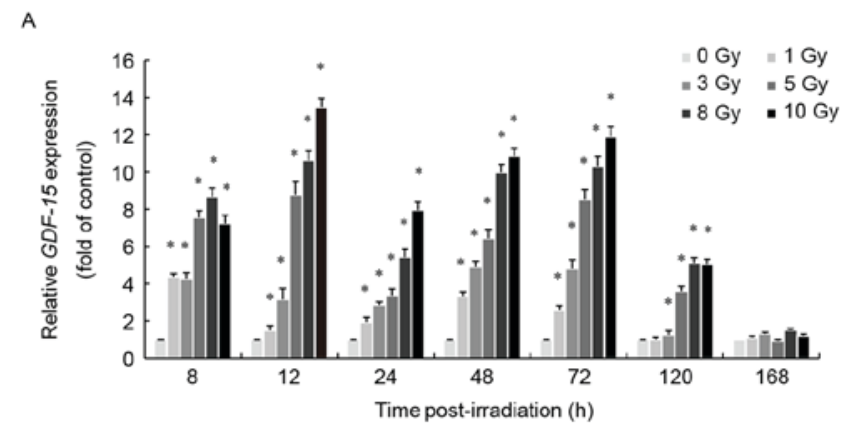

B

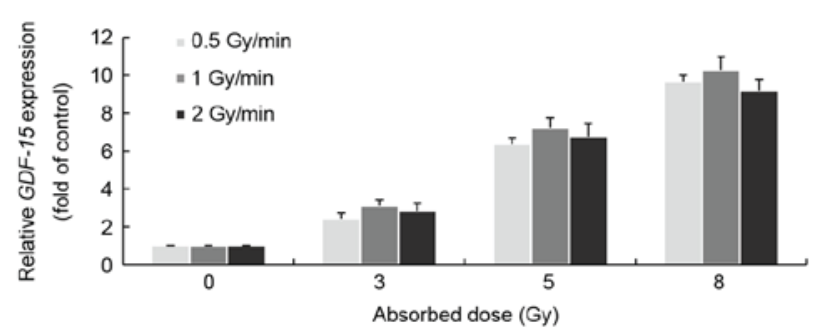

Figure 1. Exposure to $\gamma$-rays altered $G D F-15$ mRNA expression levels in AHH-1 cells. (A) AHH-1 cells were irradiated with $0-10$ Gy ${ }^{60} \mathrm{Co} \gamma$-rays at a dose rate of $1 \mathrm{~Gy} / \mathrm{min}$. Cells were collected for analysis $8-168 \mathrm{~h}$ post-irradiation. Relative GDF-15 mRNA expression levels were assessed using RT-qPCR. GDF-15 mRNA expression levels were significantly upregulated 8-120 $\mathrm{h}$ following irradiation compared with the control group (0 Gy). (B) AHH-1 cells were irradiated with 3,5 or 8 Gy of ${ }^{60} \mathrm{Co} \gamma$-rays at a dose-rate of $0.5,1$ and $2 \mathrm{~Gy} / \mathrm{min}$. Cells were collected for analysis $48 \mathrm{~h}$ post-irradiation. Relative $G D F-15 \mathrm{mRNA}$ expression levels were assessed using RT-qPCR. Alterations in GDF-15 expression depended on radiation dose, regardless of the dose rate. Data are expressed as the mean \pm standard error of the mean of three independent experiments. ${ }^{*} \mathrm{P}<0.05$ vs. 0 Gy group. GDF, growth/differentiation factor; RT-qPCR, reverse transcription-quantitative polymerase chain reaction.

assessed $48 \mathrm{~h}$ following $\gamma$-ray exposure. The present results suggested that $G D F-15$ expression depended on the radiation dose, regardless of the dose rate (Fig. 1B).

Exposure to $\gamma$-rays alters GDF-15 protein expression levels in AHH-1 cells. GDF-15 protein expression levels in AHH-1 cells were assessed using western blot analysis at 8,12, 24 and $48 \mathrm{~h}$ after exposure to $0,1,3,5,8$ and 10 Gy $\gamma$-rays. GDF-15 protein expression levels were significantly upregulated in a dose-dependent manner within a dose range of 1-8 Gy, 8-48 h following irradiation $(\mathrm{P}<0.05$; Fig. 2$) . \gamma$ irradiation appeared to reach its maximum effect ( $\sim$-fold increase compared with the control group) at 8 Gy and $12 \mathrm{~h}$ post-irradiation. The dose-response curves describing the relationship between radiation dose and GDF-15 protein expression levels between 12 and $48 \mathrm{~h}$ following exposure were fitted to a linear model $(\mathrm{P}<0.05$; Table II). No dose-response relationship was apparent at 8 and $72 \mathrm{~h}$ post-irradiation.

Exposure to neutron radiation alters GDF-15 $m R N A$ and protein expression levels in AHH-1 cells. Alterations in GDF-15 gene expression in AHH-1 cells were assessed using RT-qPCR, $48 \mathrm{~h}$ following exposure to $0,0.4,0.8$ and $1.6 \mathrm{~Gy}$ of ${ }^{252} \mathrm{Cf}$ neutron radiation. GDF-15 mRNA expression levels were significantly upregulated in a dose-dependent manner $48 \mathrm{~h}$ following irradiation $(\mathrm{P}<0.05$; Fig. $3 \mathrm{~A})$. Neutron
Table I. Equations describing the dose-response relationship between the absorbed dose (0-10 Gy) of ${ }^{60} \mathrm{Co} \gamma$-rays (dose rate, $1 \mathrm{~Gy} / \mathrm{min}$ ) and GDF-15 mRNA expression levels in AHH-1 cells.

\begin{tabular}{ccc}
\hline $\begin{array}{l}\text { Time post- } \\
\text { irradiation (h) }\end{array}$ & $\begin{array}{c}\text { Dose-response } \\
\text { equation }\end{array}$ & $\mathrm{R}^{2}$ \\
\hline 8 & $y=0.62 x+2.75$ & 0.728 \\
12 & $y=1.31 x+0.54$ & 0.963 \\
24 & $y=0.63 x+0.92$ & 0.954 \\
48 & $y=0.96 x+1.77$ & 0.978 \\
72 & $y=1.09 x+1.59$ & 0.970 \\
120 & $y=0.48 x+0.65$ & 0.914 \\
\hline
\end{tabular}

$y$, relative GDF-15 mRNA expression level (fold change); $x$, absorbed dose (Gy). GDF, growth/differentiation factor.

Table II. Equations describing the dose-response relationship between the absorbed dose ( $0-10 \mathrm{~Gy})$ of ${ }^{60} \mathrm{Co} \gamma$-rays (dose rate, $1 \mathrm{~Gy} / \mathrm{min}$ ) and GDF-15 protein expression levels in AHH-1 cells.

\begin{tabular}{lcc}
$\begin{array}{l}\text { Time post- } \\
\text { irradiation }(\mathrm{h})\end{array}$ & $\begin{array}{c}\text { Dose-response } \\
\text { equation }\end{array}$ & $\mathrm{R}^{2}$ \\
\hline 8 & - & - \\
12 & $\mathrm{y}=1.81 x-0.34$ & 0.959 \\
24 & $y=0.43 x+0.53$ & 0.962 \\
48 & $y=0.33 x+0.85$ & 0.926 \\
72 & - & - \\
120 & - & -
\end{tabular}

$y$, relative GDF-15 protein expression level (fold change); $x$, absorbed dose (Gy). GDF, growth/differentiation factor.

irradiation appeared to reach its maximum effect ( 12-fold increase compared with the control group) at $1.6 \mathrm{~Gy}$. The fitted dose-response curve describing the relationship between radiation dose and GDF-15 mRNA expression levels followed a quadratic model, described by the following equation: $y=4.85 x^{2}-1.80 x+1.35\left(\mathrm{R}^{2}=0.9769, \mathrm{P}<0.05\right)$, where $y$ represents the GDF-15 mRNA expression levels induced (fold change) by $x$ Gy of neutron radiation.

GDF-15 protein expression levels were assessed in AHH-1 cells using western blot analysis $48 \mathrm{~h}$ following exposure to $0-1.6$ Gy of neutron radiation. GDF-15 protein levels were significantly increased in a dose-dependent manner $(\mathrm{P}<0.05$; Fig. 3B). Neutron irradiation appeared to reach its maximum effect ( 4 -fold increase compared with the control group) at $1.6 \mathrm{~Gy}$. The dose-response curve describing the relationship between radiation dose and GDF-15 protein expression levels followed a linear model, described by the following equation: $y=2.11 x+1.15\left(\mathrm{R}^{2}=0.954, \mathrm{P}<0.05\right)$, where $y$ represents the GDF-15 protein expression levels induced by $x$ Gy of neutron radiation. 


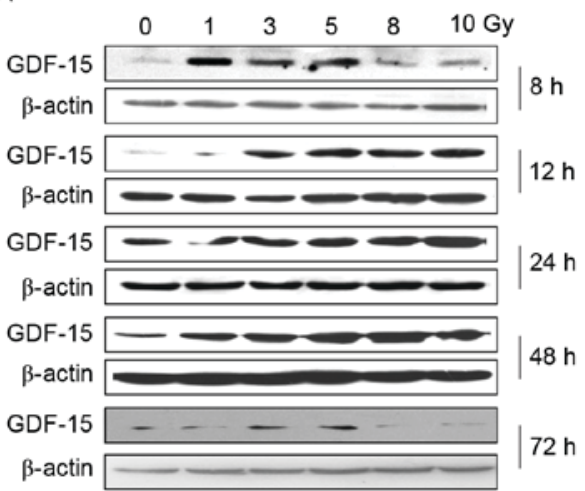

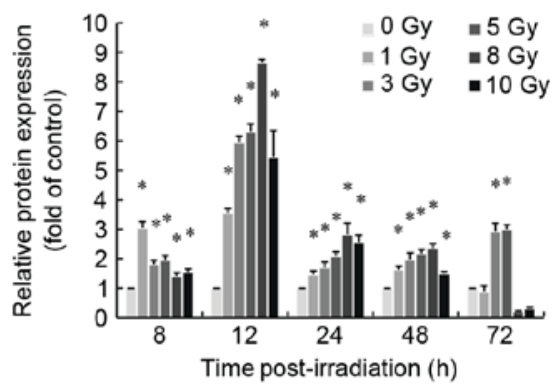

Figure 2. Exposure to $\gamma$-rays altered GDF-15 protein expression levels in AHH-1 cells. AHH-1 cells were irradiated with $0-10$ Gy of ${ }^{60} \mathrm{Co} \gamma$-rays at a dose rate of $1 \mathrm{~Gy} / \mathrm{min}$. Cells were collected for western blot analysis 8-72 h post-irradiation. (A) Representative blots demonstrating alterations in GDF-15 protein expression levels. (B) Semi-quantification of western blot analysis results, normalized to $\beta$-actin. Relative GDF-15 protein expression levels were significantly upregulated following irradiation compared with the control group $(0 \mathrm{~Gy})$. Data are expressed as the mean \pm standard error of the mean of three independent experiments. ${ }^{*} \mathrm{P}<0.05$ vs. 0 Gy group. GDF, growth/differentiation factor.

A

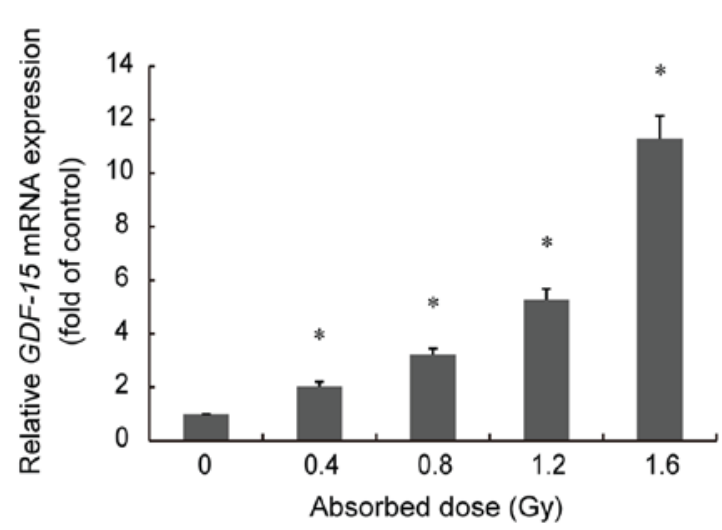

B

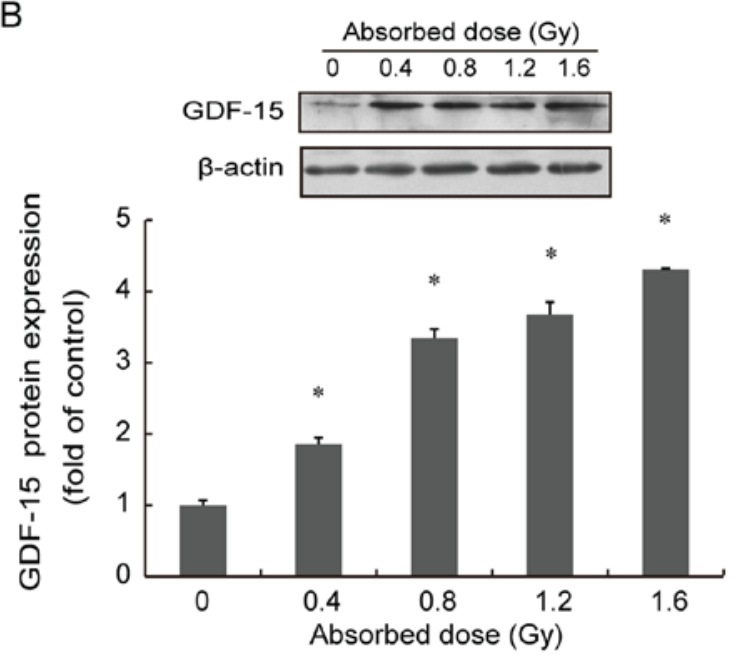

Figure 3. Exposure to neutron radiation altered GDF-15 mRNA and protein expression levels in AHH-1 cells. AHH-1 cells were irradiated with 0-1.6 Gy of ${ }^{252} \mathrm{Cf}$ neutron radiation at a dose rate of $0.073 \mathrm{~Gy} / \mathrm{min}$. (A) $G D F-15$ mRNA expression levels were significantly upregulated $48 \mathrm{~h}$ following irradiation compared with the control group (0 Gy). (B) Representative blot demonstrating alterations in GDF-15 protein expression levels. GDF-15 protein expression levels were visibly increased $48 \mathrm{~h}$ following irradiation compared with the control group (0 Gy). GDF-15 protein expression levels were normalized to $\beta$-actin. Data are expressed as the mean \pm standard error of the mean of three independent experiments. $\mathrm{P}<0.05$ vs. 0 Gy group. GDF, growth/differentiation factor.

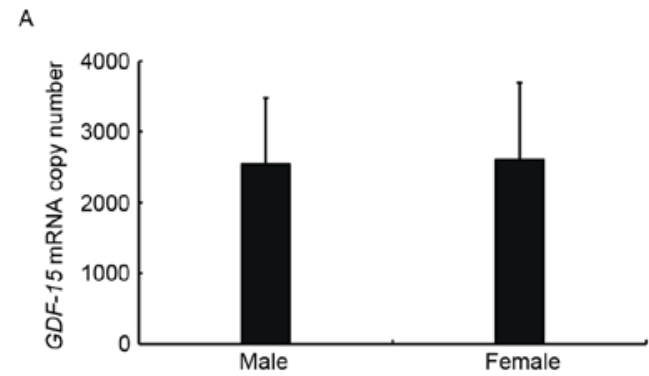

B

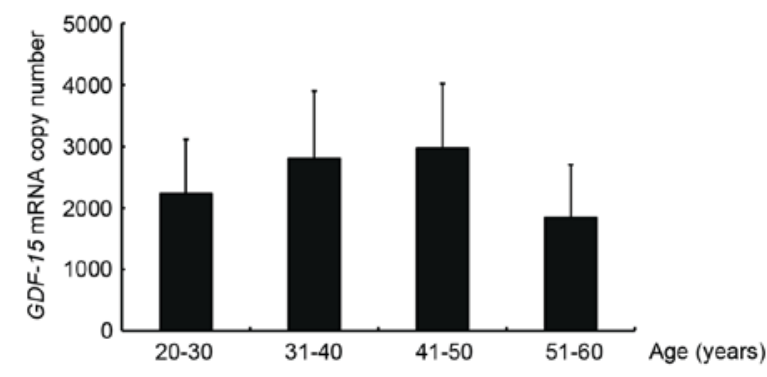

Figure 4. GDF-15 mRNA levels in peripheral blood samples of 73 healthy adult donors. (A) GDF-15 mRNA expression levels (mRNA copy numbers per $\mu$ l) in males were not significantly different compared with in females. (B) No significant differences in GDF-15 mRNA expression levels were revealed among different age groups; however, an increasing trend was observed within the 20-50 age range. Data are expressed as the mean \pm standard error of the mean of three independent experiments. GDF, growth/differentiation factor.

Baseline GDF-15 mRNA expression levels in peripheral blood samples from healthy adults. To investigate the baseline levels of $G D F-15$ gene expression in the general population, $G D F-15$ mRNA levels (mRNA copy number per $\mu \mathrm{l}$ ) were assessed in peripheral blood samples, obtained from 73 healthy adult donors. The present results demonstrated that GDF-15 mRNA expression levels in males were not significantly different compared with in females (Fig. 4A). In addition, no significant differences in GDF-15 mRNA expression levels were revealed among different age groups; however, an increasing trend was observed within the $20-50$ age range (Fig. 4B). The mean 
Table III. Equations describing the dose-response relationship between the absorbed dose (0-8 Gy) of ${ }^{60} \mathrm{Co} \gamma$-rays (dose rate, $1 \mathrm{~Gy} / \mathrm{min}$ ) and $G D F-15$ mRNA expression levels in human peripheral blood lymphocytes.

\begin{tabular}{llc}
\hline $\begin{array}{l}\text { Time post- } \\
\text { irradiation }(\mathrm{h})\end{array}$ & $\begin{array}{c}\text { Dose-response } \\
\text { equation }\end{array}$ & $\mathrm{R}^{2}$ \\
\hline 4 & $y=7,510 x+23,380$ & 0.797 \\
8 & $y=27,480 x+47,200$ & 0.970 \\
12 & $y=14,786 x+75,212$ & 0.851 \\
24 & $y=14,210 x+79,197$ & 0.955 \\
48 & $y=28,707 x+72,207$ & 0.899 \\
\hline
\end{tabular}

$y$, number of $G D F-15$ mRNA copies/ $\mu 1 ; x$, absorbed dose (Gy); GDF, growth/differentiation factor.

GDF-15 mRNA copy number was calculated and revealed to be $2573.3 \pm 2006.9$ per $\mu 1$.

Exposure to $\gamma$-rays alters GDF-15 mRNA expression levels in HPBLs. Radiation-induced alterations in GDF-15 gene expression were investigated in human peripheral blood samples obtained from three healthy donors. Samples were analyzed $4,8,12,24,48$ and $72 \mathrm{~h}$ following ex vivo irradiation with 0 , $1,3,5$ and 8 Gy of $\gamma$-rays. HPBLs were isolated and GDF-15 mRNA copy numbers were assessed with no significant differences among the three donors at each radiation dose. $G D F-15$ mRNA copy numbers were significantly upregulated in a dose-dependent manner at 4-48 $\mathrm{h}$ following $\gamma$-ray exposure $(\mathrm{P}<0.05$; Fig. 5). The dose-response curves describing the relationship between radiation dose and $G D F-15$ mRNA expression levels at different time-points were fitted to a linear model $(\mathrm{P}<0.05$; Table III). At $72 \mathrm{~h}$ following irradiation, GDF-15 mRNA copy numbers were significantly upregulated; however, no dose-response relationship was apparent $(\mathrm{P}>0.05)$.

\section{Discussion}

Radiation-responsive genes, which exhibit alterations in their expression in response to radiation exposure, may have potential as biomarkers for the evaluation of the dose of absorbed radiation. Therefore, a reproducible dose-response relationship should be established between the absorbed dose and the effect on gene expression. Previous studies have suggested that alterations in the expression of GADD45, CDKN1A and PCNA induced by ionizing radiation are time- and dose-dependent in human cell lines, HPBLs $(3,6,17,29)$ and mice $(8)$; however, the time- and dose-response relationship is not consistent among different genes, forms of radiation and cell types. GDF-15 is a member of the tumor growth factor- $\beta$ superfamily and a downstream target of p53 (42), and serves important roles in human diseases, such as cardiomyopathy (43). Previous studies have suggested that the $G D F-15$ gene may participate in $\gamma$-ray-induced DNA damage, as microarray analysis identified $G D F-15$ as a radiation-responsive gene $(19,34,36,39)$.

The present study demonstrated that GDF-15 mRNA and protein expression levels in AHH-1 cells were upregulated in a

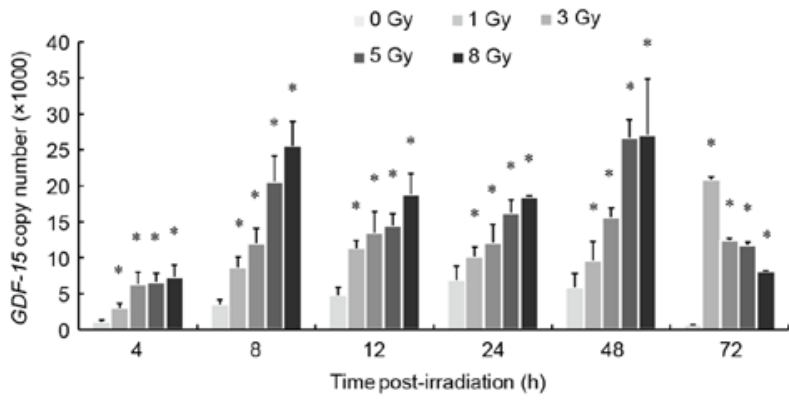

Figure 5. Exposure to $\gamma$-rays altered $G D F-15$ mRNA expression levels in HPBLs from three healthy adult donors. HPBLs were irradiated with 1-8 Gy of ${ }^{60} \mathrm{Co} \gamma$-rays at a dose rate of $1 \mathrm{~Gy} / \mathrm{min}$. Cells were collected for analysis 4-72 h post-irradiation. GDF-15 mRNA expression levels (mRNA copy number per $\mu \mathrm{l}$ ) were significantly upregulated in a dose-dependent manner 4-48 h following irradiation compared with the control group (0 Gy). Data are expressed as the mean \pm standard error of the mean of three independent experiments. ${ }^{*} \mathrm{P}<0.05$ vs. 0 Gy group. GDF, growth/differentiation factor; HPBL, human peripheral blood lymphocyte.

dose-dependent manner by 1-10 Gy of $\gamma$-rays, within 8-120 and 8-48 h following irradiation, respectively. In addition, HPBLs exposed to 1-8 Gy of $\gamma$-rays also exhibited a dose-dependent increase in GDF-15 mRNA copy number at 4-48 h post-irradiation. To the best of our knowledge, this is the first study that has demonstrated that radiation-induced alterations in $G D F-15$ expression in AHH-1 cells and HPBLs consistently follow a dose-response relationship within a wide range of doses and post-exposure time points. The present findings are consistent with previous studies on radiation-induced alterations in the expression of other genes, including GADD45, CDKN1A and p53-inducible gene 3 (PIG3) $(3,6,18,39)$. Furthermore, $G D F-15$ baseline mRNA copy number appeared to be lower, and the time-frame for detection of radiation-induced alterations in GDF-15 expression appeared to be longer compared with PIG3, which was investigated in our previous study (39). Therefore, alterations in $G D F-15$ expression may have potential as a novel radiation biomarker.

Alterations in GDF-15 mRNA and protein expression levels in AHH-1 cells were observed up to 120 and $48 \mathrm{~h}$ following $\gamma$-ray exposure, respectively. When $G D F-15$ mRNA expression was analyzed, the alterations in gene expression appeared to be lower at $120 \mathrm{~h}$ post-irradiation compared with other time points, which may be associated with longer cell culture time and cell growth status following exposure. The differences in the duration of the effects of radiation on GDF-15 mRNA and protein may be due to the gene expression regulation, which is characterized by extensive inter-correlations between the rates of transcription, translation and protein degradation. The changes in protein levels depend on the mRNA concentration, translation efficiency and degradation of the existing protein (44). Therefore, different dose-response curves should be used according to the time period after irradiation to estimate an appropriate dose of radiation.

It has previously been demonstrated that radiation-induced chromosomal abnormalities in human lymphocytes depend on the radiation dose rate (45). Notably, in the present study, radiation-induced alterations in GDF-15 gene expression in AHH-1 cells were not modulated by the dose rate $(0.5-2 \mathrm{~Gy} / \mathrm{min})$ of $\gamma$-rays, within a dose range of 3-8 Gy. Further studies, using a 
wider range of dose rates, are required to elucidate the effect of the dose rate on $G D F-15$ gene expression.

It has previously been reported that alterations in $G D F-15$ gene expression in human pulmonary epithelial cells were dose- and time-dependent, following exposure to $\alpha$-particle radiation (19). In accordance with a previous study (34), the present results demonstrated that $G D F-15$ expression was altered by $\gamma$-rays and neutron radiation. These results suggested that GDF-15 expression may have potential as a radiation biomarker, and may be used in the development of radiation-induced gene expression signatures for use in biodosimetry (45). In the present study, dose-response relationships were also established between $G D F-15$ mRNA and protein expression levels and the dose of neutron radiation, within $48 \mathrm{~h}$ after exposure. A previous study reported that chromosomal aberrations induced by high-linear energy transfer (LET) radiation conformed to a linear relationship (46). Conversely, in the present study, the dose-response curve describing neutron-induced alterations in GDF-15 expression conformed to a quadratic model.

In addition, the expression changes of GDF-15 mRNA and protein in AHH-1 cells induced by 1 Gy $\gamma$-rays at $48 \mathrm{~h}$ post-irradiated were increased by approximately three-fold and two-fold, respectively. For the neutron exposed AHH-1 cells, the expression levels of GDF-15 mRNA and protein following exposure to $1.2 \mathrm{~Gy}$ at $48 \mathrm{~h}$ were elevated to approximately four-fold and three-fold, respectively. This difference between $\gamma$-ray- and neutron-induced changes of GDF-15 mRNA and protein expression may be caused by the different radiation qualities. High-LET radiations such as neutron are highly toxic and exert a complex effect on the genomic integrity of cells, which may lead to more severe biological damage compared with that of $\gamma$-rays (17).

The present study also investigated the expression of $G D F-15$ in healthy adults. $G D F-15$ mRNA copy number did not differ significantly between sexes, or among age groups. These results indicated the consistency in GDF-15 expression, which is an essential characteristic for a potential biomarker of radiation exposure.

Alterations in $G D F-15$ expression induced by ${ }^{60} \mathrm{Co}$ $\gamma$-rays were observed for up to $120 \mathrm{~h}$ following exposure in AHH-1 cells, and $72 \mathrm{~h}$ in HPBLs. This difference may be attributed to a difference in radiation sensitivity between the two cell types. In a previous study, AHH-1 cells were irradiated during the exponential growth phase, whereas HPBLs were in non-cycling $\left(\mathrm{G}_{0}\right.$ cell cycle phase), and DNA repair capabilities differed between proliferating and non-proliferating cells (39). The present results suggested that dose-dependent alterations in $G D F-15$ expression could be observed within a limited time frame in HPBLs, and this may prove to be a limitation in future applications. Further studies, using larger sample sizes, are required to elucidate the relationship between the radiation dose and alterations in GDF-15 expression.

In conclusion, the present study demonstrated that timeand dose-dependent alterations were induced in GDF-15 mRNA and protein expression levels in AHH-1 cells by $\gamma$-rays and neutron radiation. In addition, GDF-15 mRNA expression levels in HPBLs isolated from healthy adults did not differ with age or sex. Furthermore, alterations in GDF-15 mRNA expression levels in HPBLs induced by $\gamma$-rays were revealed to be dose-dependent. These results suggested that the $G D F-15$ gene in HPBLs may have potential as a biomarker to evaluate radiation exposure. Further studies, using a larger number of human blood samples, are required to investigate the radiation-induced alterations in $G D F-15$ expression.

\section{Acknowledgements}

The authors would like to thank Dr Xiang-Yan Zhou, Dr Hui-Min Lv and Dr Wei Zhang from the National Institute for Radiological Protection, Chinese Center for Disease Control and Prevention (Beijing, China) for their help and assistance with the original study protocols. The present study was supported by the National Natural Scientific Foundation of China (grant nos. 30570551, 81172593 and 81573081).

\section{References}

1. Amundson SA, Bittner M, Meltzer P, Trent J and Fornace AJ Jr: Induction of gene expression as a monitor of exposure to ionizing radiation. Radiat Res 156: 657-661, 2001.

2. Amundson SA, Do KT, Shahab S, Bittner M, Meltzer P, Trent J and Fornace AJ Jr: Identification of potential mRNA biomarkers in peripheral blood lymphocytes for human exposure to ionizing radiation. Radiat Res 154: 342-346, 2000.

3. Amundson SA and Fornace AJ Jr: Monitoring human radiation exposure by gene expression profiling: Possibilities and pitfalls. Health phys 85: 36-42, 2003.

4. Brengues M, Paap B, Bittner M, Amundson S, Seligmann B, Korn R, Lenigk R and Zenhausern F: Biodosimetry on small blood volume using gene expression assay. Health Phy 98: 179-185, 2010.

5. Fält S, Holmberg K, Lambert B and Wennborg A: Long-term global gene expression patterns in irradiated human lymphocytes. Carcinogenesis 24: 1837-1845, 2003.

6. Grace MB, McLeland CB and Blakely WF: Real-time quantitative RT-PCR assay of GADD45 gene expression changes as a biomarker for radiation biodosimetry. Int J Radiat Biol 78: 1011-1021, 2002.

7. Kabacik S, Mackay A, Tamber N, Manning G, Finnon P, Paillier F, Ashworth A, Bouffler S and Badie C: Gene expression following ionising radiation: Identification of biomarkers for dose estimation and prediction of individual response. Int $\mathrm{J}$ Radiat Biol 87: 115-129, 2011.

8. Li MJ, Wang WW, Chen SW, Shen Q and Min R: Radiation dose effect of DNA repair-related gene expression in mouse white blood cells. Med Sci Monit 17: BR290-BR297, 2011.

9. Moulder JE: Post-irradiation approaches to treatment of radiation injuries in the context of radiological terrorism and radiation accidents: A review. Int J Radiat Biol 80: 3-10, 2004.

10. Roy L, Gruel G and Vaurijoux A: Cell response to ionising radiation analysed by gene expression patterns. Ann Ist Super Sanita 45: 272-277, 2009.

11. Amundson SA and Fornace AJ Jr: Gene expression profiles for monitoring radiation exposure. Radiat Prot Dosimetry 97: 11-16, 2001.

12. Fachin AL, Mello SS, Sandrin-Garcia P, Junta CM, Donadi EA, Passos GA and Sakamoto-Hojo ET: Gene expression profiles in human lymphocytes irradiated in vitro with low doses of gamma rays. Radiat Res 168: 650-665, 2007.

13. Fachin AL, Mello SS, Sandrin-Garcia P, Junta CM, Ghilardi-Netto T, Donadi EA,Passos GA and Sakamoto-Hojo ET: Gene expression profiles in radiation workers occupationally exposed to ionizing radiation. J Radiat Res 50: 61-71, 2009.

14. Filiano AN, Fathallah-Shaykh HM, Fiveash J, Gage J, Cantor A, Kharbanda S and Johnson MR: Gene expression analysis in radiotherapy patients and $\mathrm{C} 57 \mathrm{BL} / 6$ mice as a measure of exposure to ionizing radiation. Radiat Res 176: 49-61, 2011.

15. Gruel G, Lucchesi C, Pawlik A, Frouin V, Alibert O, Kortulewski T, Zarour A, Jacquelin B, Gidrol X and Tronik-Le Roux D: Novel microarray-based method for estimating exposure to ionizing radiation. Radiat Res 166: 746-756, 2006.

16. Kang CM, Park K, Song JE, Jeoung DI, Cho CK, Kim TH, Bae S, Lee SJ and Lee YS: Possible biomarkers for ionizing radiation exposure in human peripheral blood lymphocytes. Radiat Res 159: 312-319, 2003. 
17. Turtoi A, Brown I, Schläger M and Schneeweiss FH: Gene expression profile of human lymphocytes exposed to (211)At alpha particles. Radiat Res 174: 125-136, 2010.

18. Akerman GS, Rosenzweig BA, Domon OE, Tsai CA, Bishop ME, McGarrity LJ, MacGregor JT, Sistare FD, Chen JJ and Morris SM: Alterations in gene expression profiles and the DNA-damage response in ionizing radiation-exposed TK6 cells. Environ Mol Mutagen 45: 188-205, 2005.

19. Chauhan V and Howland M: Gene expression responses in human lung fibroblasts exposed to alpha particle radiation. Toxicol In Vitro 28: 1222-1229, 2014.

20. Grace MB, McLeland CB, Gagliardi SJ, Smith JM, Jackson WE III and Blakely WF: Development and assessment of a quantitative reverse transcription-PCR assay for simultaneous measurement of four amplicons. Clin Chem 49: 1467-1475, 2003.

21. Jen KY and Cheung VG: Transcriptional response of lymphoblastoid cells to ionizing radiation. Genome Res 13: 2092-2100, 2003.

22. Paul S and Amundson SA: Gene expression signatures of radiation exposure in peripheral white blood cells of smokers and non-smokers. Int J Radiat Biol 87: 791-801, 2011.

23. Pogosova-Agadjanyan EL, Fan W, Georges GE, Schwartz JL, Kepler CM, Lee H, Suchanek AL, Cronk MR, Brumbaugh A, Engel $\mathrm{JH}$, et al: Identification of radiation-induced expression changes in nonimmortalized human T cells. Radiat Res 175 172-184, 2011.

24. Dressman HK, Muramoto GG, Chao NJ, Meadows S, Marshall D, Ginsburg GS, Nevins JR and Chute JP: Gene expression signatures that predict radiation exposure in mice and humans. PLoS Med 4: e106, 2007.

25. Meadows SK, Dressman HK, Muramoto GG, Himburg H, Salter A, Wei Z, Ginsburg GS, Chao NJ, Nevins JR and Chute JP: Gene expression signatures of radiation response are specific, durable and accurate in mice and humans. PLoS One 3: e1912, 2008.

26. Amundson SA, Grace MB, McLeland CB, Epperly MW, Yeager A, Zhan Q, Greenberger JS and Fornace AJ Jr: Human in vivo radiation-induced biomarkers: Gene expression changes in radiotherapy patients. Cancer Res 64: 6368-6371, 2004.

27. Turtoi A, Brown I, Oskamp D and Schneeweiss FH: Early gene expression in human lymphocytes after gamma-irradiation-a genetic pattern with potential for biodosimetry. Int J Radiat Biol 84: 375-387, 2008

28. Turtoi A and Schneeweiss FH: Effect of (211)At alpha-particle irradiation on expression of selected radiation responsive genes in human lymphocytes. Int J Radiat Biol 85: 403-412, 2009.

29. Paul S and Amundson SA: Development of gene expression signatures for practical radiation biodosimetry. Int J Radiat Oncol Biol Phys 71: 1236-1244, 2008.

30. Paul S, Barker CA, Turner HC, McLane A, Wolden SL and Amundson SA: Prediction of in vivo radiation dose status in radiotherapy patients using ex vivo and in vivo gene expression signatures. Radiat Res 175: 257-265, 2011.

31. Badie C, Kabacik S, Balagurunathan Y, Bernard N, Brengues M, Faggioni G, Greither R, Lista F, Peinnequin A, Poyot T, et al: Laboratory intercomparison of gene expression assays. Radiat Res 180: 138-148, 2013.

32. Boldt S, Knops K, Kriehuber R and Wolkenhauer O: A frequencybased gene selection method to identify robust biomarkers for radiation dose prediction. Int J Radiat Biol 88: 267-276, 2012.
33. Brzóska $\mathrm{K}$ and Kruszewski M: Toward the development of transcriptional biodosimetry for the identification of irradiated individuals and assessment of absorbed radiation dose. Radiat Environ Biophys 54: 353-363, 2015.

34. Joiner MC, Thomas RA, Grever WE, Smolinski JM, Divine GW, Konski AA, Auner GW and Tucker JD: Developing point of care and high-throughput biological assays for determining absorbed radiation dose. Radiother Oncol 101: 233-236, 2011.

35. Tucker JD, Joiner MC, Thomas RA, Grever WE, Bakhmutsky MV, Chinkhota CN, Smolinski JM, Divine GW and Auner GW: Accurate gene expression-based biodosimetry using a minimal set of human gene transcripts. Int J Radiat Oncol Biol Phys 88: 933-939, 2014

36. Kis E, Szatmári T, Keszei M, Farkas R, Ésik O, Lumniczky K, Falus A and Sáfrány G: Microarray analysis of radiation response genes in primary human fibroblasts. Int $\mathbf{J}$ Radiat Oncol Biol Phys 66: 1506-1514, 2006.

37. Rødningen OK, Overgaard J, Alsner J, Hastie $\mathrm{T}$ and Børresen-Dale AL: Microarray analysis of the transcriptional response to single or multiple doses of ionizing radiation in human subcutaneous fibroblasts. Radiother Oncol 77: 231-240, 2005.

38. Warters RL, Packard AT, Kramer GF, Gaffney DK and Moos PJ: Differential gene expression in primary human skin keratinocytes and fibroblasts in response to ionizing radiation. Radiat Res 172: 82-95, 2009.

39. Liu QJ, Zhang DQ, Zhang QZ, Feng JB, Lu X, Wang XR, Li KP, Chen DQ, Mu XF, Li S and Gao L: Dose-effect of ionizing radiation-induced PIG3 gene expression alteration in human lymphoblastoid AHH-1 cells and human peripheral blood lymphocytes. Int J Radiat Biol 91: 71-80, 2015.

40. Crespi CL and Thilly WG: Assay for gene mutation in a human lymphoblast line, AHH-1, competent for xenobiotic metabolism. Mutat Res 128: 221-230, 1984.

41. Livak KJ and Schmittgen TD: Analysis of relative gene expression data using real-time quantitative PCR and the 2(-Delta Delta C(T)) Method. Methods 25: 402-408, 2001.

42. Osada M, Park HL, Park MJ, Liu JW, Wu G, Trink B and Sidransky D: A p53-type response element in the GDF15 promoter confers high specificity for $\mathrm{p} 53$ activation. Biochem Biophys Res Commun 354: 913-918, 2007.

43. Montoro-García S, Hernández-Romero D, Jover E, García-Honrubia A, Vilchez JA, Casas T, Martínez P, Climent V, Caballero L, Valdés M and Marín F: Growth differentiation factor-15, a novel biomarker related with disease severity in patients with hypertrophic cardiomyopathy. Eur J Intern Med 23: 169-174, 2012.

44. de Sousa Abreu R, Penalva LO, Marcotte EM and Vogel C: Global signatures of protein and mRNA expression levels. Mol Biosyst 5: 1512-1526, 2009.

45. Purrott RJ and Reeder E: The effect of changes in dose rate on the yield of chromosome aberrations in human lymphocytes exposed to gamma radiation. Mutat Res 35: 437-444, 1976.

46. Upton AC: Environmental standards for ionizing radiation: Theoretical basis for dose-response curves. Environ Health Perspect 52: 31-39, 1983. 